\title{
PENGARUH PENGENDALIAN PIUTANG USAHA DALAM MEMINIMALKAN PIUTANG TAK TERTAGIH PADA PT GAYA SASTRA INDAH
}

\author{
Tiara Timuriana \\ Dosen Tetap Program Studi Akuntansi D3 Fakultas Ekonomi \\ Universitas Pakuan \\ Risti Eni Nasution \\ Mahasiswa Program Studi Akuntansi D3 Fakultas Ekonomi \\ Universitas Pakuan
}

\begin{abstract}
ABSTRAK
PT Gaya Sastra Indah yang dalam kegiatan usahanya melakukan penjualan secara tunai dan secara kredit, namun pada umumnya penjualan yang dilakukan secara kredit lebih sering digunakan karena dapat meningkatkan volume penjualan. Namun, penjualan kredit menyebabkan timbulnya suatu tagihan berupa piutang usaha.

PT Gaya Sastra Indah berlokasi di Jl. Pulo Gadung II E/3 Jakarta. Maksud dan tujuan dari penelitian ini adalah: (a) untuk mengetahui penerapan pengendalian piutang usaha; (b) untuk mengetahui upaya yang dilakukan manajemen dalam meminimal piutang tak tertagih; dan (c) untuk mengetahui pengaruh pengendalian piutang usaha dalam meminimalkan piutang tak tertagih. Indentifikasi masalah dalam penelitian ini adalah: (a) bagaimana penerapan pengendalian piutang usaha; (b) bagaimana upaya untuk meminimalkan piutang tak tertagih; dan (c) bagaimana pengaruh pengendalian piutang usaha dalam meminimal piutang tak tertagih.

Berdasarkan hasil penelitian dapat disimpulkan bahwa dengan naiknya persentase piutang yang lewat jatuh tempo dari tahun ke tahun, semakin lambatnya perputaran piutang, dan semakin lamanya periode rata-rata pengumpulan piutang, maka penulis menyimpulkan bahwa pengendalian terhadap piutang belum efektif.
\end{abstract}

Kata kunci: Pengendalian Piutang, Piutang Tak tertagih, Pemberian Kredit, Penagihan, Kebijakan Pengumpulan Piutang.

\section{Pendahuluan}

Pengendalian ini biasanya melibatkan penyelidikan atas kredibilitas pelanggan, dengan menggunakan referensi dan pemeriksaan atas latar belakang pelanggan. Dengan adanya pengendalian piutang diharapkan perusahaan dapat meminimalkan terjadinya piutang tak tertagih, karena dengan timbulnya piutang tak tertagih dapat menyebabkan kegiatan perusahaan terhenti bahkan perusahaan dapat menjadi bangkrut.

PT Gaya Sastra Indah yang dalam kegiatan usahanya melakukan penjualan secara tunai dan secara kredit, namun pada umumnya penjualan yang dilakukan secara kredit lebih 
sering digunakan karena dapat meningkatkan volume penjualan dan agar dapat bersaing dengan perusahaan lain. Namun, akibat dari penjualan kredit menyebabkan timbulnya suatu tagihan berupa piutang usaha.

Piutang usaha merupakan salah satu faktor yang sangat penting untuk diperhatikan karena berpengaruh terhadap likuiditas suatu perusahaan. Hal ini dikarenakan piutang usaha termasuk ke dalam kategori aktiva lancar dan diharapkan akan dapat dicairkan dalam waktu singkat. Karena sifatnya yang dapat dicairkan dalam waktu yang singkat tanpa adanya pencatatan dan pengawasan yang baik, kesalahan dan penyelewengan terhadap piutang tersebut akan mudah terjadi. Oleh karena itu pimpinan atau pihak perusahaan harus dapat menetapkan prosedur serta metode akuntansi yang akan digunakan, pemilihan pelanggan yang layak, penagihan secara berkala kepada pelanggan, serta pencatatan akuntansi yang memadai sehingga kesalahan dan penyelewengan terhadap piutang serta kerugian akibat piutang yang tak tertagih dapat dihindari. Guna menghindari tidak tertagihnya piutang, maka PT Gaya Sastra Indah menerapkan pengendalian atas piutang dengan cara menganalisa setiap calon debitur, pemisahan antara fungsi-fungsi penjualan dan adanya pengesahan dari fungsi kredit.

Oleh karena itu, tujuan penelitian adalah sebagai berikut: 1) Untuk mengetahui penerapan pengendalian piutang usaha pada PT Gaya Sastra Indah Jakarta; 2) Untuk mengetahui upaya yang dilakukan manajemen PT Gaya Sastra Indah Jakarta dalam meminimal piutang tak tertagih; 3) Untuk mengetahui pengaruh pengendalian piutang usaha dalam meminimalkan piutang tak tertagih pada PT Gaya Sastra Indah Jakarta.

\section{Metode Penelitian}

Jenis penelitian dalam penulisan makalah ini adalah Deskriptif (eksploratif), Metode penelitian yang digunakan dalam penelitian ini adalah studi kasus. Teknik penelitian yang digunakan dalam penelitian ini adalah Deskriktif Kualitatif (non statistik), Metode Analisis yang digunakan oleh penulis adalah Deskriptif Kualitatif (non statistik).

\section{Hasil dan Pembahasan}

\subsection{Prosedur Penjualan Kredit}

Bagian-bagian yang terkait dalam prosedur penjualan kredit adalah salesman, pelanggan, kepala bagian perdagangan, bagian gudang, bagian pengiriman dan bagian akuntansi. Sedangkan dokumen-dokumen yang digunakan dalam penjualan kredit pada PT Gaya Sastra Indah adalah sales order, dan faktur penjualan. 
Catatan-catatan akuntansi yang digunakan adalah siklus penjualan kredit adalah jurnal penjualan,kartu piutang, dan kartu gudang. Prosedur penjualan kredit yang dilakukan perusahaan pada PT Gaya Sastra Indah adalah:

a. Pelanggan menghubungi perusahaan baik melalui telepon, ataupun salesman yang datang ke pelanggan, kemudian salesman membuat sales order.

b. Sales order yang telah dibuat tersebut diminta persetujuan dari kepala bagian perdagangan. Apabila pesanan dari pelanggan disetujui maka kepala bagian perdagangan akan menandatangani sales order tersebut.

c. Copy sales order lembar keempat diserahkan kepada kepala bagian keuangan untuk meminta persetujuan kredit. Bila persetujuan kredit disetujui, maka kepala bagian keuangan membubuhi tandatangan dalam copy sales tersebut. Copy sales tersebut yang telah ditandatangani diserahkan kembali kepada kepala bagian perdagangan.

d. Sales order yang telah disetujui didistribusikan, lembar kesatu diserahkan ke bagian administrasi, lembar kedua dan ketiga diserahkan ke gudang untuk mempersiapkan barangnya, lembar keempat di file.

e. Berdasarkan copy sales order, bagian administrasi umum akan membuat faktur dan membubuhi nomor faktur disales order dan mengarsipnya.

f. Oleh kepala bagian gudang faktur asli dan tiga copy faktur yang diterimanya dari bagian administrasi di cek dengan fisik atau barang yang telah disipkan melalui sales order pada point (d). Sehingga apabila ada kesalahan dalam pembuatan faktur dapat segera diketahui dan dilakukan koreksi.

g. Setelah barang yang disipkan sama dengan faktur, maka barang, faktur asli, dan tiga lembar copynya serta lembar kedua sales order diserahkan ke bagian pengiriman. Kemudian bagian pengiriman memberi paraf pada copy sales order tersebut, lembar ketiga untuk pertinggal di gudang. Kepala gudang mencatat sales order ke dalam kartu gudang.

h. Barang yang sudah disiapkan, faktur asli dan tiga lembar copy faktur dan sales order lembar kedua dibawa oleh pengantar barang ke pelanggan. Dalam hal ini sales order berfungsi sebagai tembusan surat perintah pengiriman atau pengantar barang. Barang diserahkan ke pelanggan, kemudian pelanggan menandatangani di faktur. Satu lembar copy faktur yaitu lembar keempat dan sales order diserahkan kepada pelanggan.

i. Faktur asli dan dua lembar copy faktur yang sudah ditandatangani oleh pelanggan diserahkan ke administrasi untuk disortir dan di registrasi. Faktur asli diarsip terpisah dengan 
faktur penjualan yang akan ditagih oleh bagian penagihan, dan faktur lembar ketiga untuk seksi akuntansi (pembukuan).

j. Oleh seksi akuntansi, setiap hari faktur yang diterimanya akan dicatat kedalam kartu piutang, merupakan buku pembantu yang merinci perkiraan kontrol piutang dalam buku besar.

k. Berdasarkan copy faktur penjualan seksi akuntansi akan mencatat ke dalam buku jurnal penjualan setiap hari,yaitu:

Db. Piutang $x x$

$$
\text { Kr. Penjualan xx }
$$

\subsection{Kebijakan Penjualan Kredit PT Gaya Sastra Indah}

Dalam menghadapi persaingan dari perusahaan distributor buku tulis lain pihak manajemen menetapkan kebijaksanaan pemberian kredit antara lain:

1. Untuk jangka waktu kredit, konsumen ditawarkan untuk hutangnya dalam jangka waktu 60 hari.

2. Jika konsumen dalam melunasi hutangnya lebih dari batas waktu kredit maka akan diberikan denda sebesar 5\% tiap bulannya

3. jika konsumen dalam melunasi hutangnya lebih cepat 6 hari dari batas kredit maka akan diberikan discount 3\%. untuk setiap pengajuan kredit maka calon konsumen harus membayar uang muka minimal 20\% dari harga buku tulis yang dipesannya.

\subsection{Pengendalian atas Penjualan Kredit}

Pengendalian Piutang Usaha

Ada 3 faktor yang diperhatikan dalam pengendalian atas piutang antara lain: pemberian kredit, penagihan (collection), penetapan dan penyelenggaraan intern yang layak. Berikut pengendalian piutang pada PT Gaya Sastra Indah:

1. Pemberian Kredit

Dalam menghadapi persaingan dari perusahaan distributor buku tulis lain, pihak manajemen menetapkan kebijaksanaan pemberian kredit yang ringan. Untuk jangka waktu kredit, konsumen ditawarkan untuk hutangnya dalam jangka waktu 60 hari.

Pada PT Gaya Sastra konsumen dalam melunasi hutangnya lebih dari batas waktu kredit maka akan diberikan denda sebesar 5\% tiap bulannya dan jika konsumen dalam melunasi hutangnya lebih cepat 6 hari dari batas kredit maka akan diberikan discount 3\%. Adapun penagihan piutang pada PT Gaya Sastra Indah sebagai berikut: 
a) Invoice diterbitkan dilengkapi dengan dokumen-dokumen pendukungnya. Setiap invoice yang diterbitkan harus diadministrasikan dalam register invoice, demikian juga penyerahannya kepada petugas.

b) Setiap invoice yang diserahkan kepada pelanggan melalui petugas penagihan harus dibuatkan dokumen serah terima invoice yang ditandatangani oleh pelanggan dan kemudian akan diserahkan kembali jika telah dilakukan pembayaran. Invoice yang belum terbayar harus dapat ditunjukan dokumen searah terimanya oleh petugas penagih, jika diperlukan oleh manajer keuangan.

c) Reminder Letters kepada langganan harus diterbitkan dan dikirimkan sesuai jadwal yang ditetapkan sebagai pemberitahuan kepada langganan atas piutang yang telah outstanding.

3. Penetapan dan penyelenggaraan pengendalian intern yang layak

Tinjauan customer baru yang di lakukan oleh PT Gaya Sastra Indah adalah Finance Manager berkoordinasi dengan marketing dan sales manager untuk menetapkan syarat-syarat atau prosedur bagi pelanggan baru

Finance manager bersama dengan marketing \& sales manager meninjau persyaratan kredit pelanggan yang meliputi :

-Order Quantity

-Payment Record

-Term of payment

-Customer Loyalty

a. Hasil evaluasi terhadap kredit pelanggan dan aspek-aspek tersebut diatas disajikan dalam customer profile report dan direview minimal 6 bulan sekali.

\subsection{Pengendalian atas Piutang Tak Tertagih}

Pengendalian piutang sebagai salah satu kegiatan yang dilakukan oleh manajemen yang bertujuan untuk meminimalkan resiko tidak tertagihnya piutang. Faktor untuk mengawasi piutang perusahaan perlu membuat daftar pengelompokan piutang berdasarkan umur (aging schedule)

Berdasarkan tabel yang diperoleh jumlah piutang yang lewat jatuh tempo tahun 2008 mengalami kenaikan dibandingkan dengan total piutang lewat jatuh tempo tahun 2009 yaitu 27,92\%. Dengan membandingkan piutang yang lewat jatuh tempo tahun 2008 dan 2009, dapat dilihat persentase umur piutang 31-60 hari mengalami penurunan yaitu 18,53\% menjadi $0,50 \%$, persentase umur piutang 61-90 hari mengalami kenaikan yaitu 3,61\% menjadi $4,71 \%$, 
persentase 91-120 hari mengalami kenaikan yaitu 0,05\% menjadi 1,30\%, persentase umur piutang >120 hari mengalami kenaikan yaitu 5,66\%menjadi 15,84\%.

Jumlah piutang yang lewat jatuh tempo tahun 2009 mengalami kenaikan dibandingkan dengan total piutang lewat jatuh tempo tahun 2010 yaitu 95,04\%. Dengan membandingkan piutang yang lewat jatuh tempo tahun 2009 dan 2010, dapat dilihat persentase umur piutang 31-60 hari mengalami kenaikan yaitu 0,12\% menjadi 12,66\%, persentase umur piutang 61-90 hari mengalami kenaikan yaitu 3,85\% menjadi 2,92\%, persentase 91-120 hari mengalami kenaikan yaitu $0,68 \%$ menjadi $1,07 \%$, persentase umur piutang $>120$ hari mengalami kenaikan yaitu $11,69 \%$ menjadi $83,03 \%$.

Jumlah piutang yang lewat jatuh tempo tahun 2010 mengalami kenaikan dibandingkan dengan total piutang lewat jatuh tempo tahun 2011 yaitu 57,25\%. Dengan membandingkan piutang yang lewat jatuh tempo tahun 2010 dan 2011, dapat dilihat persentase umur piutang 31-60 hari mengalami kenaikan yaitu $0,12 \%$ menjadi $12,66 \%$, persentase umur piutang $61-90$ hari mengalami penurunan yaitu 3,85\% menjadi 2,92\%, persentase 91-120 hari mengalami kenaikan yaitu $0,68 \%$ menjadi $1,07 \%$, persentase umur piutang $>120$ hari mengalami kenaikan yaitu $11,69 \%$ menjadi $83,03 \%$.

\subsection{Pengendalian Piutang Usaha dalam Meminimalkan Piutang Tak Tertagih}

Pengendalian piutang dagang adalah proses evaluasi atas kebijakan kredit yang telah dijalankan, khususnya pemantauan apabila terjadi perubahan pola pembayaran pada pelanggan. Misalnya, pelanggan yang semula tergolong patuh dalam membayar kini mulai terlambat membayar kewajibannya.

Kebijakan pengumpulan piutang yang diterapkan PT Gaya Sastra Indah adalah sebagai berikut:

1. Bagian piutang wajib memberikan surat konfirmasi piutang kepada seluruh pelanggan minimal 6 bulan sekali, untuk memastikan bahwa daftar piutang yang terdapat pada catatan perusahaan sudah sesuai dengan catatan customer.

2. Setiap pelanggan yang membayar hutangnya lebih cepat 6 hari dari batas waktu kredit maka akan diberikan discount 3\% kepada konsumen yang membayar hutangnya tepat waktu setiap 2 bulan sekali.

Untuk menjaga langkah pembayaran dari para pelanggan, pada umumnya perusahaan harus mengawasi perkiraan-perkiraan yang belum dibayar. Pertama kali, sebuah perusahaan secara normal harus menjaga rata-rata periode penagihan piutang (average collection period) serta tingkat perputaran piutang (recevable turnover). 
Berikut tabel rata-rata periode penagihan piutang (average collection period) serta tingkat perputaran piutang (recevable turnover).

a. Perputaran piutang (recevable turnover)

Pelunasan piutang usaha dari pelanggan tentu akan menjadi sumber dana yang akan digunakan bagi kegiatan operasional perusahaan. Perusahaan dapat melakukan kontrol atas piutang usaha dengan menghitung account receivable turnover.

Dari hasil perhitungan Account Receivable Turnover yang diolah penulis, dapat dilihat bahwa perputaran piutang pada tahun 2008 sebanyak 23,51 kali, tahun 2009 sebanyak 12,54 kali dan tahun 2010 sebanyak 9,85 kali dan tahun 2011 sebanyak 9,11 kali. Ini berarti pada tahun 2008 dana yang tertanam dalam piutang lebih sedikit jika dibandingkan tahun-tahun sesudahnya (tahun 2009, 2010 dan 2011). Sedangkan perputaran piutang yang paling lambat terjadi pada tahun 2011 yaitu sebanyak 19,13 kali, ini berarti terjadi kelebihan investasi.

Hasil perhitungan account receivable turnover selama tempat tahun yaitu tahun 20082011 dapat dikatakan, kebijakan kredit perusahaan kurang baik. Hal ini dapat dilihat dari tingkat perputaran piutang yang semakin menurun dari tahun ke tahun. Hal ini disebabkan terjadinya peningkatan dana yang tertanam dalam piutang.

b. $\quad$ Periode pengumpulan piutang (Average collection period)

Dari hasil perhitungan pada tahun 2008 average collection period yaitu 15 hari berarti 45 hari lebih cepat dari batas terakhir yang ditetapkan yaitu 60 hari atau 2 bulan. Pada tahun 2009 average collection period yaitu 29 hari berarti 31 hari lebih cepat dari batas terakhir yang ditetapkan yaitu 60 hari atau 2 bulan. Pada tahun 2010 average collection period yaitu 37 hari berarti 23 hari lebih cepat dari batas terakhir yang ditetapkan 60 hari atau 2 bulan. Pada tahun 2011 average collection period yaitu 40 hari berarti 20 hari lebih cepat dari batas terakhir yang ditetapkan 60 hari atau 2 bulan. Meningkatnya Average collection period dari tahun ke tahun menunjukkan pelanggan makin lambat membayar kewajibannya. Hal ini dapat dijadikan indikator awal kemungkinan timbulnya piutang tidak tertagih atau kredit macet.

\section{Simpulan}

1 Sistematika penyajian dan prosedur Standar Oprating Procedure Account Recevable pada PT Gaya Sastra Indah sudah menunjukan adanya kesinambungan prosedur antara sub prosedur yang satu dengan yang lainnya, sehingga alur dokumen dapat terlihat jelas dimulai dari mana dan berakhir dimana serta bagiam mana saja yang bertanggung jawab. 
2 Dalam prosedur penjualan kredit pada PT Gaya Sastra tidak ada bagian kredit khusus yang meneliti status dari pelanggan yang lama maupun pelanggan baru. Karena dengan adanya bagian kredit ini dapat berfungsi untuk bertanggung jawab membuat kebijakankebijakan pemberian kredit yang memadai.

3 Jangka waktu yang ditetapkan PT Gaya Sastra 60 hari. Namun, berdasarkan analisis ternyata jangka waktu yang diberikan sebelumnya adalah 60 hari tidaklah cukup. Masih banyak pelanggan yang melampaui batas waktu yang ditetapkan perusahaan.

4 Pengendalian dan pengawasan piutang yang dilakukan oleh perusahaan kurang optimal, hal ini bisa dilihat dari meningkatnya piutang yang lewat jatuh tempo yang pada tahun 2008 mengalami kenaikan sebesar 27,92\%. Dengan membandingkan jumlah piutang yang lewat jatuh tempo tahun 2009 mengalami kenaikan dibandingkan dengan total piutang lewat jatuh tempo tahun 2010 yaitu 95,04\%. Dengan membandingkan jumlah piutang yang lewat jatuh tempo tahun 2010 mengalami kenaikan dibandingkan dengan total piutang lewat jatuh tempo tahun 2011 yaitu 57,25\%. Serta menurunya rata-rata periode pengumpulan piutang antara lain tahun 2008 sebanyak 23,51 kali, tahun 2009 sebanyak 12,54 kali, tahun 2010 sebanyak 9,85 kali dan 2011 sebanyak 9,11 kali yang berarti masih banyak pelanggan yang tidak memenuhi syarat pembayaran yang telah ditetapkan oleh perusahaan. Rata-rata perputaran piutang kurang cepat hal ini mengakibatkan makin lama waktu terikatnya modal dalam piutang. Kondisi piutang selama empat tahun menunjukkan kondisi kurang baik, hal ini disebabkan karena piutang yang sudah jatuh tempo sebagian besar belum tertagih.

\section{Daftar Pustaka}

Hall, A. James. 2009. Sistem Informasi Akuntansi. Buku Dua. Edisi Empat.Alih Bahasa: Dewi Fitriasari, Deny Kuary Arnos. Jakarta: Salemba Empat.

http://www.investopedia.com/terms/d/dso.asp ( Diakses 8 oktober 2011). http://www.scribd.com/doc/82424296/analisa-pengendalian-piutang (Diakses 10 Mei 2012) http://www.scribd.com/doc/16618702/Pengendalian-Piutang (Diakses 16 Mei 2012)

Kieso, Donald E., Jerry J. Weygandt, dan Terry D. Warfield. 2010. Akuntansi Intermediate. Edisi Kesepuluh. Alih Bahasa: Emil Salim. Jilid 1. Jakarta: Erlangga. 